УДК $330.15: 504$ (043.3)

\title{
ПРИКЛАДНІ АСПЕКТИ ГЕОУПРАВЛІННЯ В ОРГАНІЧНОМУ ЗЕМЛЕРОБСТВІ
}

\author{
Г.М. Шпак \\ кандидат економі чних наук \\ Національний університет водного господарства та природокористування \\ (Україна, м. Рівне; e-mail: shpak.galochka@gmail.com)
}

3 метою підвищення ебективності виробництва в рослинництві українсъкі аграрії дедалі частіше використовують інноваційні, зокрема ГІС- та IT-технологї. За результатами проведених досліджень основних характеристик органічного виробнищтва в Україні на основі SWOT-аналізу серед сильних сторін виділено: преміальна иіна, шуорічне зростання органічного світового ринку на 10-15\%, наявність в Україні відповідних земелъних ресурсів та природно-кліматичних умов для органічного виробництва та порівняно великі площі земель, які тривалий час не використовувались у сільсъкому господарстві. Але через численні загрози втратити статус "органіка» та труднощі з виходом на нові ринки, ией бізнес, з одного боку, є прибутковим, а з іншого - доволі ризикованим. Тому для інбормаційного забезпечення інвесторів запропоновано алгоритл накладання шарів електронних карт для визначення масиву (поля), найбільи інвестииійно-привабливого для органічного виробниитва. Основні з них: карта забруднення радіонуклідами, важкими металами, тощо, карта розташування потениійних джерел забруднення, землекористування, карта грунтів, карта ландиабту та релъєбу, розташування інбраструктурних об'єктів. Серед переваг використання геоінбормаиійних систем у аграрному секторі з метою поширення органічного виробництва слід виділити можливість оиінювати властивості та продуктивність земель, моделювати системи сівозміни для органічного зеллеробства, розміщення кулътур, планувати врожайністъ кулътур, внесення добрив з візуалізацією кіниевих результатів. Незважаючи на різний алгоритл дій на етапі планування запровадження органічного землеробства, така інбормація надасть змогу як невеликим (сімейним) бермерсъким господарствам, так і великим інвесторам визначити ділянки, які найкраще відповідають всім параметрам та вимогам для ебективного ведення органічного бізнесу. А місиевим органам влади та громадянам - найраціональніше використовувати найкращі земельні ділянки та отримувати вищу орендну плату.

Ключові слова: ГІС-технологї, агропортал, геоуправління в органічному землеробстві.

Постановка проблеми. Дуже складно забезпечити ефрективне та раціональне використання земельних ресурсів у сільському господарстві в умовах, коли стрімко поширюються деградаційні процеси, змінюються клімат, збільшуються масштаби забруднення, зменшується родючість, відсутня оперативна інформація про стан земель, їх межі та використання. Щоб приймати необхідні управлінські рішення у сільському господарстві, органи влади та всі суб'єкти земельних відносин повинні бути забезпечені актуальною, повною, достовірною, адекватною, зрозумілою та доступною інформацією. На сьогодні функція моніторингу довкілля розподіляється одночасно між кількома відомствами і грунтується, в основному, на недосконалих, трудомістких і витратних методах збору та обробки даних, а брак фрінансування стримує впровадження інновацій. Через відсутність законодавчого чітко визначеного терміну, коли інформація втрачає актуальність, державні установи вважають чинними і використовують в роботі застарілі дані, яким кілька десятків років і які досі не були актуалізовані.

Тому вітчизняне сільськогосподарське виробництво потребує поглибленої інформатизації та впровадження інновацій, як-от геоуправління в аграрному виробництві, що передбачає використання технологій (супутникові знімки, датчики, GPS-навігатори, бортові комп'ютери, мобільні пристрої тощо), які роблять землеробство більш продуманим і ефективним.

Аналіз останніх досліджень і публікацій. Про необхідність та ефективність використання інорормаційних технологій для моніторингу земель з метою забезпечення їх ефективного використання піднімають питання у своїх працях В.І. Зацерковний, С.Ю. Булигін, Г.М. Ж̊олобак, В.Д. Солодкий, В.І. Пічура, Р.І. Беспалько, В.I. Лялько, В.В. Медведєв, Н.M. Куссуль, Т.Ю. Биндич, С.Р. Трускавецький, С.Е. Перфильев, В.В. Морозов та ін. [1-6].

Результати їх досліджень охоплюють низку аспектів вказаної проблеми. Зокрема, B.I. Зацерковний [1] розробив фрункціональну 
схему АгроГІС, яка дає змогу використовувати складні багатовимірні й багатокритеріальні моделі під час дослідження процесів землекористування та оцінки негативних наслідків антропогенного впливу. В.Д. Солодкий та P.I. Беспалько [2] пропонують використовувати ДЗЗта ГІС-технології для розв'язання проблем сталого розвитку та екологічної безпеки Карпат і створити центр експериментального інорормаційного сервісу «Екокосмос-Карпати».

На прикладі басейну Дніпра B.I. Пічура [3] розробив модель інтегрованої багаторівневої геоінформаційно-аналітичної системи моніторингу та управління басейновим природокористуванням із застосуванням ГІС і ДЗЗтехнологій. Також науковцем з використанням ГIC-технологій проведено оцінку придатності сільськогосподарських земель для вирощування зернових культур та проектування врожайності культур, оцінку радіаційного забруднення земель, моделювання агрохімічних показників, а також меліорованих грунтів (на прикладі Херсонської обл.).

C.P. Трускавецький, Т.Ю. Биндич [4] у рамках розробленої ними концепції пропонують створити інформаційну систему грунтоохоронного моніторингу сільськогосподарських земель з використанням методів дистанційного зондування.

Використання інноваційних, у т.ч. IT-технологій українськими аграріями в рослинництві набуває дедалі більшої популярності. Активно впроваджувати «точне землеробство» стали великі агрохолдинги країни. За допомогою сучасних технологій аграрії в стислі терміни збирають та аналізують інформацію про стан грунтового покриву великого земельного банку, розробляють рекомендації щодо посівної кампанії, захисту рослин, збору врожаю та приймають ефективні рішення. Для цього використовують супутникові карти, дистанційне зондування землі, безпілотні літальні апарати (дрони).

Нещодавно в Україні введено в дію новий унікальний сервіс для моніторингу «агропогоди»- Метео Фарм [7]. Він надає професійні метеодані для конкретних ділянок поля саме на поточний момент з детальним описом значень. Детальний метеопрогноз надається на найближчу добу, на три, п'ять та сім днів наперед. Використання таких даних надасть змогу підвищити ефективність аграрного виробництва завдяки проведенню польових робіт в оптимальні строки (температура повітря, опади); моделюванню ймовірності розвитку хвороб і шкідників на культурах та плануванню заходів для боротьби з ними; захисту майбутнього врожаю від заморозків. Вартість пакета послуг становить 200-800 євро/рік.
Допомогти фермерам мали на меті розробники порталу OneSoil — це безкоштовна агротехнічна платформа, яка працює з супутниковими знімками і дає змогу фермерам розпізнати своє поле на карті, спостерігати за станом сходів, розраховувати норми добрив, слідкувати за погодою і аналізувати дані з полів. Крім того, команда стартапу випустила інтерактивну цифрову карту сільськогосподарських даних (OneSoil Map), яка налічує понад 57 млн оцифрованих полів з усієї Свропи і Сполучених Штатів Америки, а також дані щодо 20 типів сільськогосподарських культур, зібрані за останні три роки [8].

Розробники мобільних додатків також пропонують аграріям безкоштовні спеціальні програми для смарторонів, які мають на меті спростити управління фермою і допомогти швидше приймати управлінські рішення. Наприклад, додаток Farmlogs показує багатофункціональні карти для планування посівів (карти грунту, щоб визначитися з внесенням добрив; складає звіт про кількість опадів і температури, а також робить карту врожайності і здійснює історичний опис вирощування культури). Такі додатки також допомагають вирахувати кількість рослин та інтервал розсадження (Planting population calculator), розрахувати обсяги внесення поживних речовин, щоб досягти бажаного рівня врожайності обраної культури (Fertilizer Removal by Crop), контролювати посадку і збір врожаю, відстежувати місце зберігається продукції і пункти реалізації, вести журнал обслуговування техніки (Farm at Hand), розрахувати оптимальний уміст азоту в грунті (Corn $\mathrm{N}$ rate calculator), розрахувати витрати на догляд за врожаєм (Extreme Beans) [9].

Використання такого роду інновацій особливо актуально за умов переходу до органічного землеробства, де за планування виробництва необхідно дотримуватися чітких вимог до виробництва та враховувати низку потенційних ризиків. Вітчизняним органічним виробникам, агрономам, фермерам наразі вже є доступним новий мобільний додаток Organic Helper [10], що створено як інформаційну платформу. У ньому є каталог органічних добрив і засобів захисту рослин, а ще можна отримати консультаційні послуги від фрахівців.

Виділення невирішених раніше частин загальної проблеми. Всі зазначені розробки створено на допомогу аграріям у виконанні складних управлінських та виробничих завдань через інфрормаційне забезпечення. У сучасних умовах збір та обробка необхідної інформації, ускладнюється тим, що її розпорядниками (власниками) є різні державні та 


\section{МОТИВИ ПЕРЕХОДУ ДО ОРГАНІЧНОГО ВИРОБНИЦТВА}

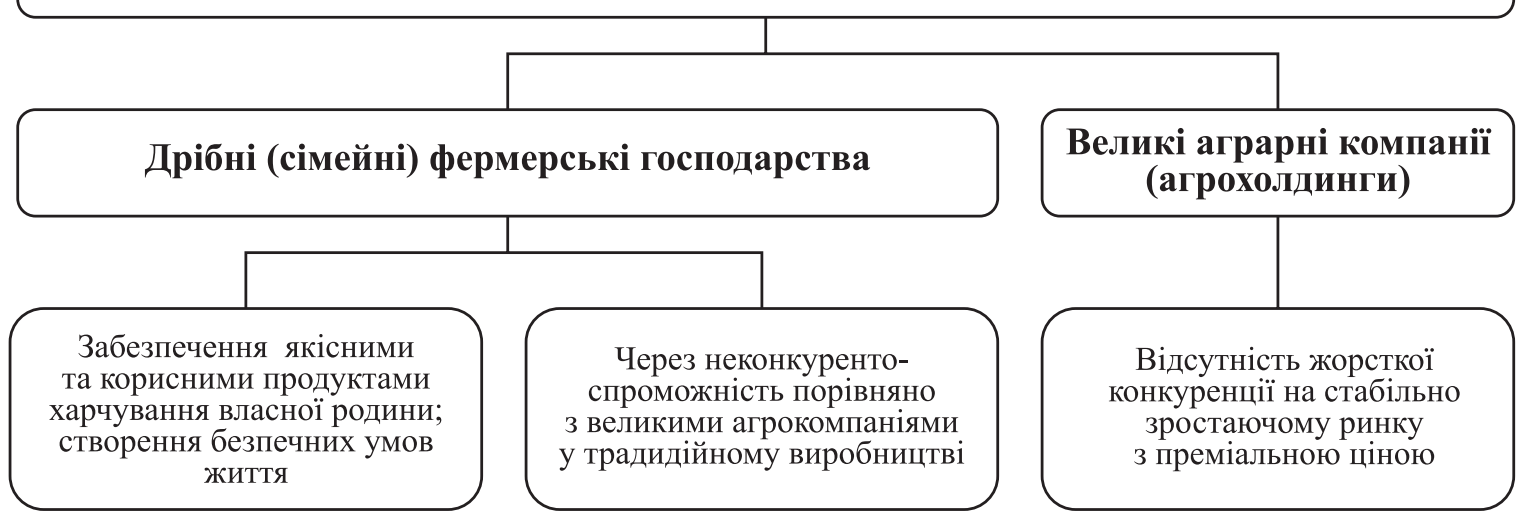

Рис. 1. Мотиви переходу агровиробників на органічні технологї

приватні установи, організації, підприємства, наукові установи.

Метою дослідження є обгрунтування переваг геоуправління з використанням інноваційних технологій для оцінки передумов та планування впровадження органічного землеробства.

Виклад основного матеріалу. У світі органічне виробництво — вже більше ніж тренд. Це соціально відповідальний бізнес, що дбає про майбутнє наступних поколінь та планети. В Україні також з'явилися аграрії, які готові інвестувати в інноваційний напрям сільськогосподарського виробництва і вважають його перспективним та прибутковим. Такими $\epsilon$ дрібні фермерські господарства 3 площею 10-50 га, і великі виробники (агрохолдинги), що обробляють від кількох сотень до кількох тисяч гектарів земель. Мотиви переходу агровиробників на органічні технології у кожного з них є різними (рис. 1).

Як свідчить практика, органічне землеробство має більше загроз, ризиків і слабких сторін порівняно з традиційним (рис. 2). Це спричинено тим, що в органічному виробництві природні чинники мають значно більший вплив на кількість та якість врожаю та більш суворий контроль за дотриманням стандартів виробництва.

На початку 2019 р., Інститут землеробства НААН представив розроблену карту придатності грунтів для органічного землеробства. Зони поділено за еколого-генетичною придатністю: на дуже придатні, придатні, умовно та мало придатні. Оптимальними для органічного землеробства, згідно із картою, виявилися Харківська, Полтавська, Вінницька, Хмельницька, Тернопільська та Чернівецька області. Найменше придатними — Київська, Чернігівська,
Рівненська, Волинська, Херсонська та Луганська області [11].

Проте у жодних міжнародних чи національних стандартах немає обмежень для сертиорікації земель як органічних, окрім рівня вмісту забруднюючих речовин (пестицидів, важких металів тощо) чи загрози забруднення. Тобто органічними можуть бути грунти будь-якого типу і з різним вмістом гумусу. А що на них вирощувати, інвестор вирішує сам. Тому, на нашу думку, під час обгрунтування ефективності переходу до органічного землеробства, необхідно зібрати та проаналізувати великий обсяг різнопланової інорормації про поле (масив), перед тим як визначати його інвестиційну привабливість для органічного виробництва (рис. 3).

Застосування ГІС-технологій значно спростить виконання поставленого завдання та сприятиме поширенню органічного виробництва, оскільки уможливить:

- проведення інвентаризації сільськогосподарських земель (області, району, господарства) та виявлення масивів (полів), придатних для запровадження органічного виробництва;

- здійснення економіко-математичного моделювання або оптимізації використання земель;

- розроблення автоматизованих варіантів землекористування з одночасним врахуванням всіх складових та обмежувальних чинників для органічного виробництва;

- оцінювання властивостей та продуктивності земель (вмісту гумусу та основних поживних речовин, оцінки поширення деградаційних процесів (наслідків вітрової та водної ерозії, засолення, підтоплення, заболочення) та розробки заходів для їх усунення);

- аналіз агрохімічних та еколого-токсикологічних показників, а також показників ча- 


\begin{tabular}{|c|c|}
\hline СЛАБКІ СТОРОНИ & ЗАГРОЗИ \\
\hline $\begin{array}{l}\text { - Жорсткі вимоги до виробництва, переробки } \\
\text { і збуту органічної продукції. } \\
\text { • Додаткові витрати на щорічну сертифікацію. } \\
\text { • Обов'язковий перехідний період упродовжк } \\
\text { 2-3 років, що збільшує термін окупності } \\
\text { інвестицій. } \\
\text { - Обмежений перелік дозволених для } \\
\text { застосування засобів захисту рослин і добрив. } \\
\text { - Брак фахівців вузького профілю, } \\
\text { відпрацьованої технології, досвіду. } \\
\text { - Суворий документообіг у господарстві. } \\
\text { - Вищу експортну ціну забезпечують умови } \\
\text { стабільності поставок якісної однорідної } \\
\text { продукції. } \\
\text { - Відсутність прямої державної фінансової } \\
\text { підтримки органічних виробників в Україні. } \\
\text { - Незавершена земельна реформа. } \\
\text { - Відсутність національних стандартів } \\
\text { органічного виробництва. } \\
\text { - Висока ціна продукції на внутрішньому ринку. }\end{array}$ & $\begin{array}{l}\text { - Додаткові вимоги щодо перевірки якості } \\
\text { кожної партії продукції, призначеної } \\
\text { на експорт. } \\
\text { - Значна кількість джерел потенційного } \\
\text { забруднення органічних угідь (промислові } \\
\text { об'єкти, сусідні інтенсивні господарства } \\
\text { тощо). } \\
\text { - Радіоактивне забруднення продукції } \\
\text { радіонуклідами. } \\
\text { - Брак сезонних робітників через значну } \\
\text { трудову міграцію населення. } \\
\text { - Розірвання або не продовження договору } \\
\text { оренди землі. } \\
\text { - Найменше порушення правил органічного } \\
\text { виробництва призведе до десертифікації } \\
\text { земель та продукції. Для поновлення } \\
\text { сертифіката обов'язковим є повторне } \\
\text { проходження перехідного періоду упродовж } \\
2-3 \text { років. } \\
\text { - Проблеми зі збутом продукції під час виходу } \\
\text { на новий ринок. }\end{array}$ \\
\hline $\begin{array}{l}\text { - Відсутність жорсткої конкуренції на ринку. } \\
\text { - Розвиток внутрішнього ринку органічної } \\
\text { продукції та зміна ставлення суспільства до } \\
\text { якості та безпеки продуктів харчування. } \\
\text { - Розвиток науки в регіоні, вдосконалення } \\
\text { технологій. } \\
\text { - Фінансова підтримка органічних виробників } \\
\text { на регіональному рівні. } \\
\text { - Налагодження переробки в кооперації, що } \\
\text { надасть змогу отримати додатковий прибуток. } \\
\text { - Обмін досвідом. В Україні є приклади } \\
\text { успішних органічних виробників. }\end{array}$ & $\begin{array}{l}\text { - Преміальна ціна. } \\
\text { - Щорічне зростання органічного світового } \\
\text { ринку на 10-15\%. } \\
\text { - Наявність відповідних земельних ресурсів } \\
\text { та природно-кліматичних умов для } \\
\text { органічного виробництва. Порівняно } \\
\text { великі площі земель, що тривалий час не } \\
\text { використовувались у сільському } \\
\text { господарстві. } \\
\text { - Близькість до кордонів з СС та Азією. }\end{array}$ \\
\hline МОЖлЛИвОСТI & СИЛЬНІ СТОРОНИ \\
\hline
\end{tabular}

Рис. 2. Матрицяя характеристик органічного виробництва в Україні на основі SWOT-аналізу

сової динаміки, їх змін у грунтах з подальшим просторовим моделюванням;

- прогнозування можливих змін агроекологічних властивостей грунту;

- моделювання системи сівозміни для органічного землеробства, розміщення культур, планування урожайності культур, внесення добрив з візуалізацією кінцевих результатів;

- підвищення точності розрахунків та прогнозів явищ і подій у навколишньому природному середовищі з виділенням головних чинників і наслідків;

- здійснення моніторингу стану і розвитку посівів культур;
- оперативне отримання точних даних та створення тематичних електронних карт (моделі рельєфру, крутизни схилів, грунтів, забруднення) під час планування запровадження органічного землеробства.

Якщо інвестор уже визначився із сорерою органічного виробництва (вирощування зернових, ягід, овочів чи тваринництво) і має чіткі вимого до місцевості та грунтів, пошарове накладання електронних карт надасть змогу запропонувати фермеру найпридатніші масиви для обраного виду діяльності. Сімейні фермерські господарства мають локальне місце розташування і доволі часто прив'язані до 


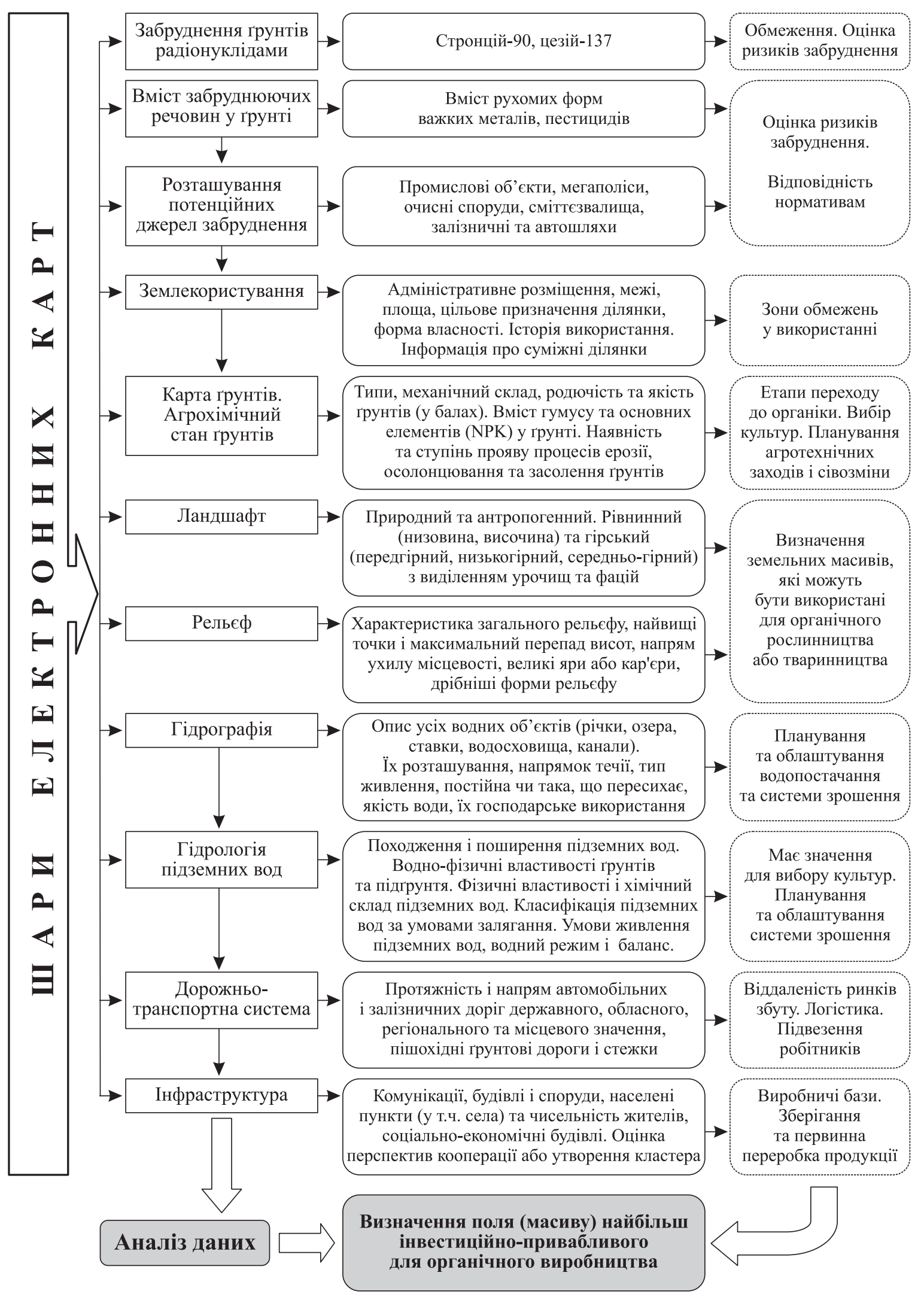

Рис. 3. Алгоритл накладання шарів електронних карт для визначення масиву (поля), найбільш інвестииійно-привабливого для органічного виробництва 
місця проживання фермера: на етапі планування запровадження органічного землеробства - інший алгоритм дій (рис. 4, 5).
Використання інорормаційних технологій в управлінні аграрним виробництвом допоможе:

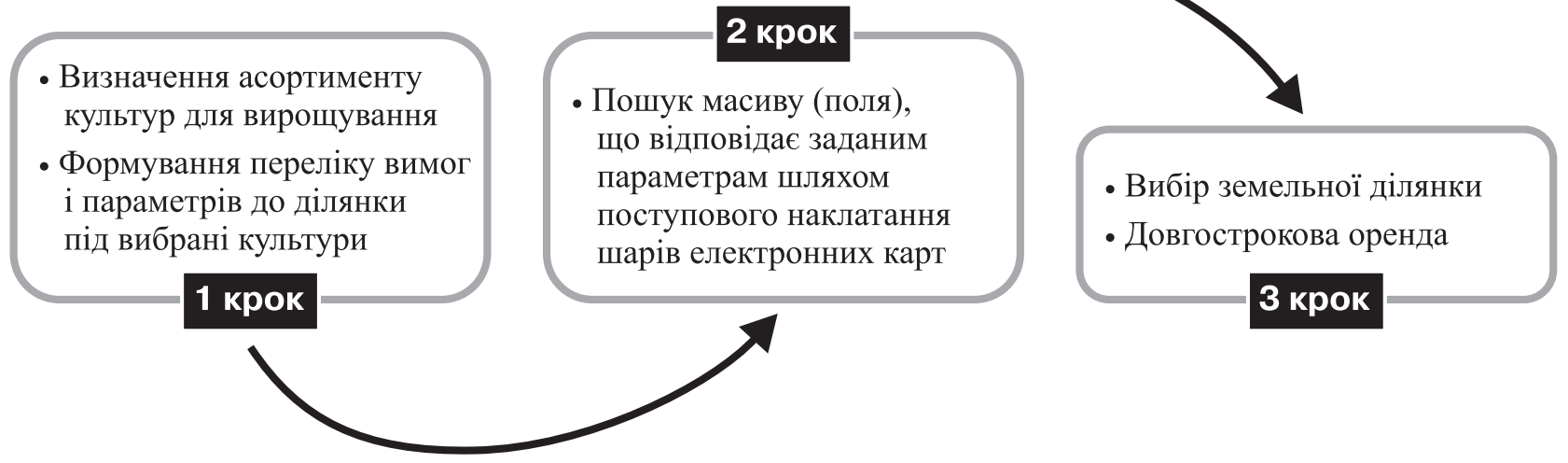

Рис. 4. Алгоритл дій інвестора на етапі планування запровадження органічного землеробства

- Власна або вже орендована земельна ділянка

- Прив'язка до місця проживання

\section{1 крок}

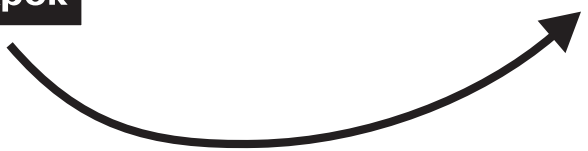

\section{2 крок}

- Оцінка властивостей масиву (поля) та пошук критичних точок

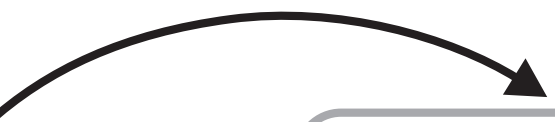

- Визначення асортименту культур, які можна вирощувати на обраній ділянці $з$ найменшими витратами

\section{3 крок}

Рис. 5. Алгоритм дій дрібного фбермера на етапі планування запровадження органічного землеробства

- місцевим органам влади, громадам найраціональніше використовувати найкращі земельні ділянки, отримувати вищу орендну плату, розвивати виробництво органічної продукції з більшою доданою вартістю переважно на експорт, не завдаючи шкоди навколишньому природному середовищу, а навпаки - сприяючи його відтворенню;

- форемерам і власникам паїв - обрати сореру діяльності (органіка чи традиційне виробництво), здати в оренду чи започаткувати власне господарство;

- інвесторам визначити ділянки, які найкраще відповідають всім параметрам та вимогам для успішного запровадження органічного виробництва, адже від цього залежатиме доцільність та обсяг майбутніх інвестицій на вирощування органічної продукції рослинництва.

Висновки. На сьогодні використання інноваційних технологій є обов'язковою складовою в сучасному ефективному сільському господарстві, а використання геоінформаційних систем для постійного моніторингу за станом земель надає змогу своєчасно виявляти зміни, оцінювати їх, запобігати виникненню й усувати наслідки негативних процесів, здійснювати контроль за використанням і станом земельних та інших ресурсів, сприятиме прийняттю едективних управлінських рішень та поширенню органічного землеробства. Подальші дослідження будуть спрямовані на розробку Е-калькулятора для моделювання сівозміни та автоматизованого процесу розрахунку балансу гумусу в грунті за умов органічного землеробства. 


\section{СПИСОК ВИКОРИСТАНИХ ДЖЕРЕЛ}

1. Зацерковний В.І. Застосування геоінформаційних систем у задачах ефективного землекористування // Наукові праці Чорноморського державного університету імені Петра Могили комплексу «КиєвоМогилянська академія». Серія: Техногенна безпека. Радіобіологія. 2015. Т. 261. Вип. 249. С. $14-21$.

2. Солодкий В.Д., Беспалько P.І., Казімір I.І. Дистанційне зондування землі як метод кадастрової ідентифікації природних ресурсів Карпатського регіону Міжвідомчий науково-технічний збірник «Геодезія, картографія і аерофотознімання». 2013. Вип. 78. С. 222-225.

3. Пічура B.I. Теоретико-методологічні основи басейнової організації природокористування на водозбірних територіях транскордонних річок (на прикладі басейну Дніпра): автореф. дис.... д-ра с.-г. наук, спец. 03.00.16. Дніпропетровський державний аграрно-економічний університет. Дніпро: 2017. $41 \mathrm{c}$.

4. Трускавецький С.Р., Биндич Т.Ю. та ін. Концепція створення інформаційної системи грунтоохоронного моніторингу методами дистанційного зондування. К.: Аграрна наука, 2017. 60 с.

5. Перфильев С.Е. Технологии ГИС-картографирования ДДЗ в космическом аграрнопромышленном мониторинге [Электронний ресурс]. URL: http://www.gisa.ru/53045.ht (дата звернення: 10.04.2019).

6. Морозов В.В., Надточій П.П., Морозов О.В., Пічура В.І. Управління водними і земельними ресурсами на базі ГІС: навчальний посібник. К.: Аграрна освіта, 2012. 349 с.

7. Незалежний метеосервіс «Метео Фарм»: [Електронний ресурс]. URL: https://www.meteo.farm (дата звернення: 10.04.2019).

8. Безкоштовна платформа для точного землеробства «OneSoil»: [Електронний pecypc]. URL: https:// onesoil.ai/ru/ (date of accesse: 10.04.2019).

9. 6 бесплатных мобильных приложений для фермеров, которые помогут в бизнесе: [Електронний peсурс]. URL: https://aggeek.net/ (дата звернення: 21.03.2019).

10. Офіційний сайт «OrganicHelper»: [Електронний ресурс]. URL: https://organic-helper.com (дата звернення: 10.04.2019).

11. Карта придатності грунтів для органічного землеробства. Офіційний сайт «Інститут землеробства HAAH»: [Електронний ресурс]. URL: http://naas.gov.ua/news/?ELEMENT_ID=5028 (дата звернення: 10.04.2019).

\section{Інформація про автора}

Шпак Галина Миколаївна — кандидат економічних наук, викладач, Технічний коледж Національного університету водного господарства та природокористування (Україна, 33027, вул. Орлова, 35, e-mail: shpak.galochka@gmail.com)

H.N. Shpak

$\mathrm{PhD}$ in Economics

National University of Water and Environmental Engineering (Ukraine, Rivne; e-mail: shpak.galochka@gmail.com)

\section{APPLIED ASPECTS OF GEO-MANAGEMENT IN ORGANIC FARMING}

In order to increase the efficiency of crop production, Ukrainian farmers increasingly use innovative, in particular GIS and IT technologies. According to the results of the conducted researches of the main characteristics of organic production in Ukraine on the basis of SWOT-analysis, among the strengths allocated - the premium price, the annual growth of the organic world market by 10-15\%, the availability of appropriate land resources and natural and climatic conditions in Ukraine for organic production and relatively large areas of land that have long been not used in agriculture. But because of numerous threats of losing the status of organic matter and the difficulties of entering new markets, this business is not only profitable but also very risky. Therefore, for providing information to investors, an algorithm for overlaying layers of electronic maps for determining the array (field) of the most investment-attractive for organic production is proposed. The main ones are: a map of contamination (radionuclides, heavy metals, etc.), map of the location of potential sources of pollution, land use, soil map, landscape map and relief, location of infrastructure objects. Among the advantages of using geoinformation systems in the agricultural sector for the purpose of spreading organic production, it is necessary to allocate the opportunity to evaluate the properties and productivity of land, to model crop rotation systems for organic farming, to place crops, plan crops, and fertilize with the visualization of the final results. Despite the different algorithm of action at the planning stage for organic farming, such information will allow both small (family) farms and large investors to identify the sites that best fit all the parameters and requirements for the effective conduct of organic business. And local authorities and citizens - the most rational use of the best land, get a higher rent. 
Keywords: GIS-technology, agropoltal, geo-management in organic farming.

\section{REFERENCES}

1. Zatserkovnyj, V.I. (2015). Zastosuvannia heoinformatsijnykh system u zadachakh efektyvnoho zemlekorystuvannia [Application of geographic snformation systems in the problems of effective land use]. Naukovi pratsi Chornomors'koho derzhavnoho universytetu imeni Petra Mohyly kompleksu "KyievoMohylians'ka akademiia» [Scientific works of the Petro Mohyla Black Sea State University], 249. 14-21. (In Ukr.).

2. Solodkyy, V.D., Bespal'ko, R.I., Kazimir, I.I. (2013). Dystantsiyne zonduvannya zemli yak metod kadastrovoyi identyfikatsiyi pryrodnykh resursiv Karpatskoho rehionu [Remote sensing as a method of identifying natural resources inventory of the Carpathian region]. Heodeziya, kartohrafiya i aerofotoznimannya [Geodesy, cartography and aerial photography], 78, 222-225. (In Ukr.).

3. Pichura, V.I. (2017). Teoretyko-metodolohichni osnovy basejnovoi orhanizatsii pryrodokorystuvannia na vodozbirnykh terytoriiakh transkordonnykh richok (na prykladi basejnu Dnipra): avtoreferat dysertatsiyi doktora sil's'kohospodars'kykh nauk [Theoretical and methodological bases of basin organization of nature management in catchment areas of transboundary rivers (for example, the Dnipro basin): the author's abstract of the dissertation of the doctors of agricultural sciences]. Dnipro state agrarian and economic university, 41 p. (In Ukr.).

4. Truskavets'kyy, S.R. \& Byndych, T.Yu. (2017). Kontseptsiya stvorennya informatsiynoyi systemy hruntookhoronnoho monitorynhu metodamy dystantsiynoho zonduvannya [The concept of creating an information system for monitoring the protection of soil by remote sensing methods]. Kyiv: A hrarna nauka. 60. (In Ukr.).

5. Perfilyev, S.E. (2009). Tekhnologii GIS-kartografirovaniya DZZ v kosmicheskom agropromyshlennom [GIS mapping technologies for remote sensing in the space agro-industrial. [Electronic source]. URL: http://www.gisa.ru/53045.ht (date of accesse: 10.04.2019). (In Rus.).

6. Morozov, V.V. Nadtochy, P.P., Morozov, O.V., Pichura, V.I. (2012). Upravlinnya vodnymy i zemel'nymy resursamy na bazi HIS [Management of water and land resources based on GIS]. Kyiv: Ahrarna osvita. 349. (In Ukr.).

7. Nezalezhnyy meteoservis «Meteo Farm». [Independent Meteoservice «Meteo Farm»]. [Electronic source]. URL: https://www.meteo.farm (date of accesse: 10.04.2019). (In Ukr.).

8. Bezkoshtovna platforma dlya tochnoho zemlerobstva «OneSoil» [Free platform for precision farming «OneSoil»]. [Electronic source]. URL: https://onesoil.ai/ru (date of accesse: 10.04.2019). (In Ukr.).

9. 6 besplatnykh mobil'nykh prilozheniy dlya fermerov, kotoryye pomogut v biznese [6 free mobile applications for farmers who will help in business]. [Electronic source]. URL: https://aggeek.net/ (date of accesse: 10.04.2019). (In Rus.).

10. Ofitsiynyy sayt «OrganicHelper» [Official site «OrganicHelper»]. [Electronic source]. URL: https://organic-helper.com (date of accesse: 10.04.2019). (In Ukr.).

11. Karta prydatnosti gruntiv dlya orhanichnoho zemlerobstva [Soil suitability map for organic farming]. Ofitsiynyy sayt «Instytut zemlerobstva Natsional'noyi akademiyi ahrarnykh nauk». Official site «Institute of Agriculture of the National Academy of Agrarian Sciences». Electronic source]. URL: http://naas.gov.ua/news/?ELEMENT_ID=5028 (date of accesse: 10.04.2019). (In Ukr.).

\section{Author}

Shpak Halyna Mykolaivna - PhD in Economics, teacher, Technical College of the National University of Water and Environmental Engineering (Ukraine, 33027 Rivne, st. Orlov, 35; e-mail: shpak. galochka@gmail.com) 